June 2014

\title{
The Rebirth of Federal Takings Review? The Courts' "Prudential" Answer to Williamson County's Flawed State Litigation Ripeness Requirement
}

J. David Breemer

Follow this and additional works at: https://digitalcommons.tourolaw.edu/lawreview

Part of the Constitutional Law Commons, Land Use Law Commons, and the Property Law and Real Estate Commons

\section{Recommended Citation}

Breemer, J. David (2014) "The Rebirth of Federal Takings Review? The Courts' "Prudential” Answer to Williamson County's Flawed State Litigation Ripeness Requirement," Touro Law Review. Vol. 30: No. 2, Article 8.

Available at: https://digitalcommons.tourolaw.edu/lawreview/vol30/iss2/8

This Article is brought to you for free and open access by Digital Commons @ Touro Law Center. It has been accepted for inclusion in Touro Law Review by an authorized editor of Digital Commons @ Touro Law Center. For more information, please contact Iross@tourolaw.edu. 


\title{
The Rebirth OF Federal TAKINGS RevieW? The COURTS" "PRUdENTIAL" ANSWER TO WILlIAMSON COUNTY'S FLAWED STATE LITIGATION RIPENESS REQUIREMENT
}

\author{
J. David Breemer
}

\section{INTRODUCTION}

In the 1985 decision of Williamson County Regional Planning Commission v. Hamilton Bank of Johnson City, ${ }^{1}$ the Supreme Court articulated one of the most controversial and puzzling constitutional principles of the modern era: the idea that one must unsuccessfully sue for monetary compensation in state court before asserting in federal court that a local government or a state has taken property in violation of the Takings Clause. ${ }^{2}$

Commentators have long criticized this state court litigation requirement as a concept that exists without a logical or doctrinal basis and as a rule that is self-defeating and unfair in practice because it nullifies, instead of secures, federal court review. ${ }^{3}$ Indeed, applica-

\footnotetext{
* Principal Attorney, Pacific Legal Foundation.

$1 \quad 473$ U.S. 172 (1985).

2 Id. at 194-97. Although the Williamson County Court designed the state litigation requirement to apply only to federal takings claims seeking a remedy under the Fifth Amendment's "Just Compensation" Clause, some courts have extended the requirement to federal due process and equal protection claims arising from land use disputes. See generally J. David Breemer, Ripeness Madness: The Expansion of Williamson County's Baseless "State Procedures" Takings Ripeness Requirement to Non-Takings Claims, 41 URB. LAW. 615 (2009). This aspect of the state litigation doctrine is beyond the scope of this paper.

3 Michael M. Berger \& Gideon Kanner, Shell Game! You Can't Get There from Here: Supreme Court Ripeness Jurisprudence in Takings Cases at Long Last Reaches the SelfParody Stage, 36 URB. LAw. 671, 673 (2004) [hereinafter Shell Game]; Michael M. Berger, Supreme Bait \& Switch: The Ripeness Ruse in Regulatory Takings, 3 WASH. U. J.L. \& POL'Y 99, 102 (2000); J. David Breemer, You Can Check Out But You Can Never Leave: The Story of the San Remo Hotel-The Supreme Court Relegates Federal Takings Claims to State Courts Under a Rule Intended to Ripen the Claims for Federal Review, 33 B.C. ENVTL. AfF. L. REv. 247, 283-98 (2006) [hereinafter The Story of the San Remo Hotel]; J. David Breemer, Overcoming Williamson County's Troubling State Procedures Rule: How The
} 
tion of the rule has resulted in so many unjust "anomalies" in federal takings jurisdiction that four Supreme Court justices called it "mistaken" in the 2005 decision of San Remo Hotel v. City and County of San Francisco, ${ }^{4}$ and urged its reconsideration. ${ }^{5}$

To date, the Court has declined to directly reassess Williamson County's state litigation ripeness doctrine. Nevertheless, since San Remo, the doctrine has weakened considerably. Ten years ago, the state litigation requirement was an inevitable and nearly insurmountable barrier to federal court review of a takings claim. This is no longer true. The doctrine is now often waived by courts and evaded by takings litigants. ${ }^{6}$

This shift has its genesis in recent Supreme Court decisions, including San Remo, that have indirectly undercut the state litigation requirement by holding that it is a "prudential" ripeness rule. ${ }^{7}$ Lower courts have leveraged this development to transform the state litigation requirement into a discretionary ripeness concept ${ }^{8}$ that they can decline to apply. ${ }^{9}$ The courts' increasing utilization of this approach allows some takings claimants into federal court and neutralizes the harshest results flowing from enforcement of Williamson County ripeness doctrine, namely, its tendency to combine with preclusion ${ }^{10}$ and federal removal rules ${ }^{11}$ to totally deny judicial review to takings

England Reservation, Issue Preclusion Exceptions, and the Inadequacy Exception Open the Federal Courthouse Door to Ripe Takings Claims, 18 J. LAND USE \& ENVTL. L. 209, 210 (2003) [hereinafter Overcoming]; Peter A. Buchsbaum, Should Land Use Be Different? Reflection on Williamson County Regional Planning Board v. Hamilton Bank, in TAKING SIDES ON TAKINGS Issues 471, 473-74 (Thomas E. Roberts ed., 2002); Gregory Overstreet, Update on the Continuing and Dramatic Effect of the Ripeness Doctrine on Federal Land Use Litigation, 20 Zoning \& Plan. L. ReP. 25, 27 (1997); Scott A. Keller, Judicial Jurisdiction Stripping Masquerading as Ripeness: Eliminating the Williamson County State Litigation Requirement for Regulatory Takings Claims, 85 TEX. L. REV. 199, 240 (2006).

545 U.S. 323 (2005).

$5 \quad$ Id. at 341 (Rehnquist, J., concurring).

6 See Overcoming, supra note 3, at 264.

7545 U.S. at 351 n.2 (Rehnquist, J., concurring); Stop the Beach Renourishment v. Fla. Dep't of Envtl. Prot., 560 U.S. 702, 728 (2010).

8 See Overcoming, supra note 3, at 212.

$9 \quad$ See infra note 61 and accompanying text.

10 Claim and issue preclusion rules generally bar federal courts from adjudicating cases raising issues or claims that were previously litigated by the same parties in a prior lawsuit. See Allan v. McCurry, 449 U.S. 90, 94-96 (1980); see also infra notes 68-70 and accompanying text.

11 The reference here is to the right of defendants to remove cases raising federal issues from state court to federal court under the federal removal statute, 28 U.S.C. $\$ 1441$ (b) (2006). See infra note 68 and accompanying text. 
claimants. $^{12}$

The "prudential" transformation of Williamson County's state litigation ripeness requirement, and its resulting decline as a barrier to federal takings review, is not uniform across federal circuits. Nevertheless, it is occurring. This paper reviews recent federal court decisions that have loosened the state litigation ripeness barrier to federal takings review based on its "prudential" character. Part II provides relevant background on Williamson County and the development of the state litigation rule. It explores the logic underlying the rule and the problems it causes in application. Part III reviews the judicial shift away from a jurisdictional understanding of the state litigation rule-under which compliance with the rule is a prerequisite to a court's power to hear a takings claim - to a prudential view in which application of the state litigation rule lies within the court's discretion. The article then reviews circuit court decisions that have declined to enforce the state litigation rule. It concludes that courts act correctly when they view the prudential nature of the state litigation rule as a license to balance fairness and other considerations in deciding whether to apply or not apply the rule, and that this understanding provides a partial solution to the jurisdictional confusion and inequity resulting from Williamson County.

\section{The ORIGIN OF THE STATE LITIGATION RIPENESS DOCTRINE AND ITS FLAWS IN THEORY AND IN APPLICATION}

\section{A. Williamson County's Facts and Procedure}

The Williamson County case arose from a dispute over development of a residential cluster subdivision outside Nashville, Tennessee. ${ }^{13}$ After the developer constructed a portion of the approved subdivision, Williamson County altered the zoning rules, lowering allowable building densities. ${ }^{14}$ This undercut the final phases of the project and required the developer to resubmit its plat for review under the new rules. The county planning commission (Commission) rejected the resubmitted plan as inconsistent with its new, reduced

\footnotetext{
12 See infra notes 68-70, and accompanying text.

13 Hamilton Bank of Johnson City v. Williamson Cnty. Reg'l Planning Comm'n, 729 F.2d 402, 406 n.5 (6th Cir. 1984), rev'd, 473 U.S. 172 (1985).

14 Williamson Cnty., 473 U.S. at 178.
} 
density standards. ${ }^{15}$ The developer then went bankrupt and its interests were acquired by Hamilton Bank (Bank). ${ }^{16}$

The Bank resubmitted a plat for the final phase of the subdivision after it acquired the subject property, but that too was rejected. ${ }^{17}$ The Bank then sued the Commission in federal court, alleging that denial of the plat caused a taking without just compensation and violated the Bank's due process rights. ${ }^{18}$ A jury invalidated the plat denial, and awarded the Bank damages for a temporary taking of its property interests. ${ }^{19}$ However, the trial judge granted judgment for the County notwithstanding the jury verdict. ${ }^{20}$ The Sixth Circuit subsequently reversed the lower court, upholding the jury verdict. ${ }^{21}$ The Commission then successfully petitioned the Supreme Court for certiorari.

\section{B. The Creation of the State Litigation Rule}

\section{The Williamson County Opinion}

On certiorari, the issue before the Court in Williamson County was "whether Federal, State, and Local governments must pay money damages to a landowner whose property allegedly has been 'taken' temporarily by the application of government regulations." ${ }^{22}$ Yet, in its opinion, the Court ignored this issue and focused instead on the ripeness of the Bank's claims.

In a decision authored by Justice Blackmun, the Court initially ruled that the Bank's federal takings claim was not ripe because the Commission had not reached a "final decision" as to application of its restrictions to the Bank's property. ${ }^{23}$ More specifically, the Court held that the Bank could have sought exceptions, in the form of variances, to soften some of the Commission's subdivision restrictions. ${ }^{24}$ Since the Bank did not do so, the Commission's re-

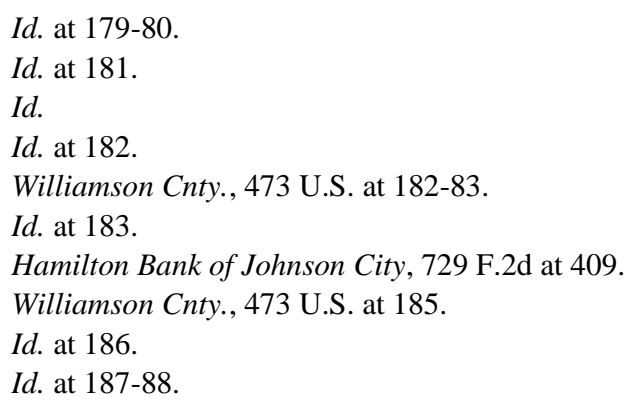


strictions were not final, and without such finality, the Court explained, it could not apply federal takings standards to the Commission's decisions to determine if they violated the Bank's rights under the Takings Clause. ${ }^{25}$

Although the Williamson County Court's final decision ripeness analysis effectively ended the case, the Court went on to apply a second, entirely novel ripeness barrier to the Bank's claim. ${ }^{26}$ The Court held that the Bank's federal takings claim was unripe not only because the Commission had not yet made a final agency decision, but also because the Bank failed to use state procedures potentially capable of providing it with just compensation. ${ }^{27}$ Starting from the premise that the Fifth Amendment does not prohibit takings of property, but only takings "without just compensation," the Court concluded that a property owner cannot claim a violation of the Takings Clause "until it has used the [state's] procedure[s] and been denied just compensation." 28

Applying this new rule in Williamson County, the Court held that the Bank's federal takings claim was premature because it had failed to use Tennessee's inverse condemnation procedure-a judicial action. ${ }^{29}$ Courts soon interpreted this part of Williamson County to mean that takings plaintiffs must unsuccessfully litigate for compensation in state courts to ripen their takings claim. ${ }^{30}$ The "state procedures" ripeness concept has thus become known as the "state litigation" ripeness requirement. ${ }^{31}$

25 Id. at 191.

26 Id. at 194.

27 Williamson Cnty., 473 U.S. at 194.

$28 \quad I d$. at 194-95.

29 Id. at 196-97.

30 See Austin v. Honolulu, 840 F.2d 678, 680 (9th Cir. 1987) (“"[A] landowner must seek and be denied compensation through state procedures, including an inverse condemnation action in state court . . . ."); Snaza v. City of St. Paul, 548 F.3d 1178, 1181-82 (8th Cir. 2008) ("Under Williamson Cnty., a property owner may not bring a federal claim for violation of the Just Compensation Clause until it has exhausted any available state procedure ... Minnesota has an adequate procedure . . by which individuals may seek just compensation in its [state] district courts."); Peters v. Clifton, 498 F.3d 727, 733 (7th Cir. 2007) (stating the plaintiff "has not met his burden of demonstrating that it would be futile to pursue available remedies in state court" to satisfy Williamson Cnty.); Pascoag Reservoir \& Dam, LLC v. Rhode Island, 337 F.3d 87, 93 (1st Cir. 2003) ("The Rhode Island Constitution prohibits the taking of private property for public use without just compensation and Rhode Island state courts have long allowed recovery through suits for inverse condemnation. Thus, Rhode Island has an adequate process available to address [the] suit for just compensation.") (emphasis added).

31 San Remo, 545 U.S. at 349 (Rehnquist, J., concurring). 
In San Remo, the Court held that the state litigation requirement does not apply in state courts. ${ }^{32}$ After San Remo, a property owner may file a federal takings claim along with state law claims in state court without first demonstrating that she has sought compensation through a state's procedures. ${ }^{33}$ Thus, the state litigation requirement is a federal court ripeness requirement only.

\section{The Questionable Logic Behind the State Litigation Rule}

For almost thirty years, the state litigation rule has dominated the federal courts' consideration of federal takings claims. It is therefore appropriate to briefly consider the doctrinal propriety of the rule.

As previously noted, the Williamson County Court derived the state litigation requirement from the "without just compensation" portion of the Takings Clause. ${ }^{34}$ Based on this language, the Court reasoned that there is no actionable taking until a takings claimant seeks and is denied compensation, and thus is "without just compensation." 35 This led the Court to conclude that a property owner must use state court procedures capable of providing compensation before a federal takings claim accrues. ${ }^{36}$

On the surface, this syllogism might appear unremarkable. But a closer look reveals at least two problematic assumptions underlying the Court's reasoning. First, the Court's logic wrongly assumes that the Just Compensation Clause functions solely as a promise that monetary damages will follow after an invasion of property. ${ }^{37}$

There is no obvious reason to adopt this narrow, remedial

32 Id. at 346 (stating Williamson Cnty. "does not preclude state courts from hearing simultaneously a plaintiff's request for compensation under state law and a claim that, in the alternative, the denial of compensation would violate the Fifth Amendment of the Federal Constitution").

33 Id.; see also Kitchen v. City of Newport News, 657 S.E.2d 132, 139 (2008) ("In [San Remo Hotel], the Supreme Court specifically rejected the 'contention that Williamson County forbids plaintiffs from advancing their federal claims in state courts.' ").

34 Williamson Cnty., 473 U.S. at 194-95.

35 Id.; see also id. at 195 n.13 ("[B]ecause the Fifth Amendment proscribes takings without just compensation, no constitutional violation occurs until just compensation has been denied. The nature of the constitutional right therefore requires that a property owner utilize procedures for obtaining compensation before bringing a $\$ 1983$ action.”).

36 Id. at 194-95.

37 Id. at 195-96 (analogizing to the Tucker Act, which authorizes damages against the United States, and requiring the Bank to use an inverse condemnation procedure, which provided a right to "sue for damages"). 
construction. The "just compensation" language of the Takings Clause is as easily conceived of as a condition precedent to the exercise of the government's power to take property, as a post-takings damages guarantee. ${ }^{38}$ And in fact, courts consistently followed the former reading until Williamson County. ${ }^{39}$ Under pre-Williamson precedent, a property owner could enjoin the government from taking property if it did so without first paying adequate compensation or establishing a mechanism for its prompt payment, and also potentially sue for damages that had already occurred. ${ }^{40}$ A violation of the Takings Clause thus accrued at the time of the property invasion, if there was no statutory or administrative provision at that time which ensured prompt payment of compensation to the property owner. ${ }^{41} \mathrm{Wil}_{\text {- }}$

38 See, e.g., Cherokee Nation v. S. Kan. Ry. Co., 135 U.S. 641,659 (1890) ("[T]he owner is entitled to reasonable, certain and adequate provision for obtaining compensation before his occupancy is disturbed."); see generally Robert Brauneis, The First Constitutional Tort: The Remedial Revolution in Nineteenth-Century State Just Compensation Law, 52 VAND. L. REV. 57, 60 (1999); Overcoming, supra note 3, at 219-20 (reading the "without just compensation" language as a condition on the government's power to invade private property as consistent with the purpose of the Bill of Rights as a whole: to limit the government's power to invade individual rights).

39 See Joshua D. Hawley, The Beginning of the End? Horne v. Department of Agriculture, and the Future of Williamson County, 2013 CATo Sup. Cт. Rev. 245, 251-57 (2013); Brauneis, supra note 38 , at 60-61.

40 Brauneis, supra note 38, at 67-68; Thacher v. Dartmouth Bridge Co., 35 Mass. 501, 502 (1836) ("[S] upposing that the act could be so construed, as to confer a power on the corporation to take private property for public use, without providing for an equitable assessment, and for the payment of an adequate indemnity, the act would, in this respect, be in contravention of the constitution of this Commonwealth, and in this respect void ... the consequence would be, that the party damaged would be remitted to his [damages] remedy at common law."); State v. Chicago, M. \& St. P. Ry. Co., 31 N.W. 365, 366 (Minn. 1887) ("So far as the section [of a legislative act] requires railroad companies to let other persons into possession of any portion of their land without the compensation required by the constitution, it is invalid."); In re Application for Drainage of Lands between Lower Chatham \& Little Falls, 35 N.J.L. 497 (Sup. Ct. 1872) (stating that just compensation is satisfied when an act authorizing taking provided for means to deduce and disburse compensation); see also Brauneis, supra note 38, at 65 ("If the plaintiff's [takings] argument prevailed, the court declared the legislation void, and the defendant's justification failed. Once the defendant was stripped of his justification, the plaintiff could recover the retrospective damages normally allowed under his common law action, and could obtain prospective relief by means of an action of ejectment or a suit in equity seeking an injunction.").

41 See Hawley, supra note 39, at 248-50; Agins v. City of Tiburon, 598 P.2d 25, 28 (Cal. 1979) (" "[I]f regulative legislation is so unreasonable or arbitrary as virtually to deprive a person of the complete use and enjoyment of his property, it comes within the purview of the law of eminent domain. Such legislation is ... invalid as an exercise of the power of eminent domain since no provision is made for compensation.") (quoting 1 NiCHOLS, EMINENT DomaIN § 1.4291 (3d rev. ed. 1978)); Cribbs v. Benedict, 44 S.W. 707, 709 (Ark. 1897) ("[I]f it be conceded that compensation . . . is not provided in the act, that fact would not render it void, but only ineffectual to take the land in invitum."). 
liamson County sharply diverged from this historic view in construing the Just Compensation Clause as simply a right to seek damages for an already completed property invasion, and from there, concluding that a violation of the Takings Clause does not accrue until some post-invasion process shows that damages will not be forthcoming.

The state litigation requirement is faulty, even if one accepts the Court's post-takings damages view of the Just Compensation Clause, because it rests on a second logical fallacy: that a taking occurs without damages only when a state court refuses to award them. Why should the post-invasion actions of a court determine whether an invasion of property is accompanied by damages; i.e, whether a taking is "without just compensation?"42 The state court is not the entity taking property. ${ }^{43}$ Takings almost always arise from the acts of a local government or a state agency, and these entities' obligation to pay compensation arises at the time of the taking, not later. ${ }^{44}$ Given these principles, it seems apparent that the actions and authority of the entity causing the taking should determine whether damages will be forthcoming and thus, whether (still accepting Williamson's remedial/damages view of the Just Compensation Clause) a claim for a violation of the Takings Clause has accrued.

The Williamson County Court never explained why it opted to hinge the "without just compensation" determination on a state

42 Shell Game, supra note 3, at 694 ("There is nothing in . . . the language of the Fifth Amendment that requires municipal nonpayment [of compensation] to be certified by a state court before it is complete.").

43 In Stop the Beach, a plurality of the Court held that courts could effect a "judicial taking" if they distorted state law so as to strip property owners of settled, pre-existing property rights. See Stop the Beach, 560 U.S. at 715 ("If a legislature or a court declares that what was once an established right of private property no longer exists, it has taken that property . . .."). Interestingly, the plurality appeared to hold that the remedy for a taking effected by a state court would be invalidation of the decision, not damages. Id. at 723. This suggests that a person whose property is taken by a state court need not ask that court for "just compensation" before he has an actionable federal takings claim. Id. On the other hand, under Williamson Cnty., one whose property is taken by a non-judicial agency; i.e., an executive or legislative entity, must unsuccessfully ask a court that did not carry out the taking for damages before his takings claim against the responsible entity accrues. 473 U.S. at 194-95.

44 San Diego Gas \& Elec. Co. v. City of San Diego, 450 U.S. 621, 654 (1981) (Brennan, J., dissenting) (stating that the government's duty to pay just compensation is triggered "[a]s soon as private property has been taken."); United States v. Clarke, 445 U.S. 253, 258 ("[T]he usual rule is that the time of the invasion constitutes the act of taking and "[i]t is that event which gives rise to the claim for compensation.' ") (quoting United States v. Dow, 357 U.S. 17, 22 (1958)); see also United States v. Dickinson, 331 U.S. 745, 751 (1947) (The takings defendant's compensatory "obligation" accrues at the time of the taking.). 
court's denial of damages, rather than on the acts, omissions and authority of the entity taking property. No good explanation can be found. State entities are generally not liable for the constitutional infractions of political subdivisions. ${ }^{45} 42$ U.S.C. Section 1983, under which most federal takings claims are raised, independently binds local governments to the Fifth Amendment. ${ }^{46}$ And the Supreme Court has repeatedly emphasized that individuals asserting a violation of their rights by a local government in federal court under 42 U.S.C. Section 1983 need not exhaust state judicial remedies. ${ }^{47}$ All of this confirms that a property owner should have a complete claim for a federal taking when the agency causing the taking has no provision or authority to pay damages at the time of the taking, not-as Williamson County holds - when a state court refuses to award damages afterward. ${ }^{48}$

\section{The State Litigation Rule Turns "Ripe" Claims into Dead Ones and Allows Removing Defendants to Deprive Property Owners of a Judicial Forum for their Takings Claim}

The Williamson County Court's decision to hinge the issue of whether a taking has occurred without just compensation, and thus, whether an actionable takings claim exists, on a state court judgment has profound practical consequences. By requiring a would-be takings plaintiff to go through state court litigation, the Court ensured

45 Caldwell v. Comm'rs of Highways of Towns of Scott, Mahomet, \& Sangamon, 94 N.E. 490, 493 (Ill. 1911) (stating the state typically "assumes no liability" for local government takings).

46 Monell v. Dep't of Soc. Servs. of City of New York, 436 U.S. 658, 690-92 (1978).

47 Steffel v. Thompson, 415 U.S. 452, $472-73$ (1974) (stating that in Section 1983 cases, "we have not required exhaustion of state judicial or administrative remedies, recognizing the paramount role Congress has assigned to the federal courts to protect constitutional rights").

48 See Henry Paul Monaghan, State Law Wrongs, State Law Remedies, and the Fourteenth Amendment, 86 Colum. L. REV. 979, 989 (1986) ("No authority supports use of ripeness doctrine to bar federal judicial consideration of an otherwise sufficiently focused controversy simply because corrective state judicial process had not been invoked."); John F. Preis, Alternative State Remedies in Constitutional Torts, 40 ConN. L. REV. 723, 726 (2008) (stating that a civil rights plaintiff relies on state remedies, including in takings cases, and such reliance is a "marked change in past practice."); Michael Wells, "Available State Remedies" and the Fourteenth Amendment: Comments on Florida Prepaid v. College Savings Bank, 33 Loy. L.A. L. REv. 1665, 1667 ("A central principle of constitutional law . . . is that the constitutional violation is complete when officials act, even if their conduct is not authorized by state law."). 
that such a plaintiff would run head-on into other potentially conflicting federal doctrines, such as claim and issue preclusion and removal jurisdiction, that conspire to defeat, rather than secure, judicial review of Fifth Amendment takings claims.

\section{Preclusion Doctrines Bar Federal Review of Takings Claims Ripened by State Litigation}

Williamson County clearly conceived of the state litigation rule as a temporary bar to federal judicial review of takings claims, ${ }^{49}$ but in practice it functions as a total bar to that review.

The central problem is that prosecution of a state court "just compensation" suit will trigger application of the Full Faith and Credit $\mathrm{Act}^{50}$ at the federal level when the takings plaintiff tries to file a federal action. The Full Faith and Credit Act requires federal courts to apply the state law doctrines of "claim preclusion" (otherwise known as res judicata) and "issue preclusion" (otherwise known as collateral estoppel) to suits that replicate prior judicial actions. ${ }^{51}$ Under preclusion principles, federal courts may not hear claims that were or could have been litigated in a prior suit between the same parties, and it also may not adjudicate issues that were raised in a prior state court suit involving the same events. ${ }^{52}$

A straightforward application of preclusion rules bars any federal suit arising after a prior state court action on the same claims or issues, whether for ripeness purposes or otherwise. Thus, when a property owner litigates in state court to ripen a takings claim for review in a federal court, in compliance with Williamson County, this very action will preclude the promised federal review. ${ }^{53}$

\footnotetext{
49 Williamson Cnty., 473 U.S. at 194 n.13 (1985) (“[A] property owner [must] utilize procedures for obtaining compensation before bringing a [section] 1983 action.") (emphasis added); see also DLX, Inc. v. Kentucky, 381 F.3d 511, 520 (6th Cir. 2004); Dodd v. Hood River Cnty., 59 F.3d 852, 861 (9th Cir. 1995) ("We disagree . . . with the suggestion that Williamson County is a thinly-veiled attempt by the Court to eliminate the federal forum for Fifth Amendment taking plaintiffs ....").

5028 U.S.C. $\S 1738$ (1948).

51 The Act specifically provides that "judicial proceedings ... . shall have the same full faith and credit in every court within the United States and its Territories and Possessions as they have by law or usage in the courts of such State . . ." Id.; In Allen v. McCurry, 449 U.S. 90, 94-95 (1980), the Court explained that the Act required federal courts to apply the claim and issue preclusion rules of the states.

52 San Remo, 545 U.S. at 336 n.16.

$53 \quad$ Id. at 333.

Williamson and its progeny place Plaintiffs in a precarious situation.
} 
As the Seventh Circuit has explained:

Although the Williamson line of cases that requires the property owner to seek compensation in the state courts speaks in terms of "exhaustion" of remedies, that is a misnomer. For if . . . the property owner goes through the entire state proceeding, and he loses, he cannot maintain a federal suit. The failure to complain of the taking under federal as well as state law is a case of "splitting" a claim, thus barring by virtue of the doctrine of res judicata a subsequent suit under federal law. ${ }^{54}$

In short, a Fifth Amendment takings claim ripened by prior state court litigation is a claim that must normally be dismissed in federal court under one or more variations of res judicata and collateral estoppel. $^{55}$

Although some lower federal courts have attempted to create exceptions to preclusion doctrine ${ }^{56}$ that would allow takings claims ripened through state litigation in federal court, the Supreme Court rejected this approach in San Remo. ${ }^{57}$ The Court held that federal courts could not excuse "ripe" federal takings claims from preclusion barriers simply because Williamson County forced the plaintiff to sue in state court first. ${ }^{58}$

Four justices led by former Chief Justice Rehnquist issued a

Plaintiffs must seek redress from the State court before their federal taking claims ripen, and failure to do so will result in dismissal by the federal court. However, once having gone through the State court system, plaintiffs who then try to have their federal claims adjudicated in a federal forum face, in many cases, potential preclusion defenses. This appears to preclude completely litigants such as those in the case at bar from bringing federal taking claims in a federal forum . . . .

W.J.F. Realty Corp. v. Town of Southampton, 220 F. Supp. 2d 140, 146 (E.D.N.Y. 2002).

54 Rockstead v. City of Crystal Lake, 486 F.3d 963, 968 (7th Cir. 2007).

$55 D L X$, Inc., 381 F.3d at 520. If the federal claim is actually raised in state court, it is barred in any later suit by the simplest form of claim preclusion. If it is left out of the state court suit, it "is a case of "splitting" " a claim, and the claim is barred from the later suit because it could have been raised in the prior suit. Rockstead, 486 F.3d at 968. Moreover, the plaintiff is barred under issue preclusion from re-litigating any factual and legal issues litigated in the state court. San Remo, 545 U.S. at 336.

56 See Santini v. Conn. Hazardous Waste Mgmt. Serv., 342 F.3d 118, 130 (2d Cir. 2003), abrogated by San Remo, 545 U.S. at 323; Fields v. Sarasota Manatee Airport Auth., 953 F.2d 1299, 1305-06 (11th Cir. 1992).

57545 U.S. at 331.

$58 \quad I d$. 
concurring opinion in San Remo, which criticized the state litigation ripeness doctrine and urged the Court to overrule the doctrine in the "appropriate case." 59 But no justice was prepared to take such a step in San Remo itself. ${ }^{60}$ Consequently, San Remo left Williamson County's state litigation predicate for federal takings review intact, while confirming that preclusion rules will usually prevent federal review of fully ripe claims. ${ }^{61}$ As the San Remo Court stated, this scheme leaves property owners with only one option for litigating their federal takings claim: they must raise it in the initial state court action required by Williamson County. ${ }^{62}$ They must use it in state court litigation or they will lose it. ${ }^{63}$

Commentators have rightly castigated the state litigation/preclusion trap as an unjust and unjustified scheme for stripping property owners of their ability to protect their federal constitutional rights in a federal court, in the same manner as other classes of citizens. $^{64}$ While San Remo approved of this framework, it did so with-

$59 \quad$ Id. at 352 (Rehnquist, C.J., concurring).

$60 \quad I d$. at 340 (majority opinion).

61 Not surprisingly, lower federal courts continued to issue contradictory directions on the availability of federal jurisdiction over a federal takings claim under Williamson Cnty. For instance, in Braun v. Ann Arbor Charter Township, the Sixth Circuit stated, "in order for a plaintiff to bring a takings claim in federal court, he or she must first pursue available remedies in state court." 519 F.3d 564, 569 (6th Cir. 2008). But the same year, the same court declared in Trafalgar Corporation v. Miami County Board of Commissioners, that because "the issue of just compensation under the Takings clause ... was directly decided in a previous state court action, it cannot be re-litigated in federal district court." 519 F.3d 285, 287 (6th Cir. 2008).

62 San Remo, 545 U.S. at 323.

63 It bears noting that a would-be federal takings claimant has no escape from the preclusion trap. He cannot, for instance, avoid preclusion barriers at the federal level by filing and litigating a state court complaint that does not include a federal takings claim. While the most straightforward form of federal claim preclusion (that barring re-litigation of a previously litigated claim) would not bar the takings claim in this scenario, the claim would still be subject to, and barred by issue preclusion or claim-splitting barriers (could have been litigated in a prior suit) when it arrives in federal court. See San Remo, 545 U.S. at 338 (discussing issue preclusion); Rockstead, 486 F.3d at 968 (discussing claim-splitting).

64 See James W. Ely, Jr., "Poor Relation" Once More: The Supreme Court and the Vanishing Rights of Property Owners, 2005 Cato Sup. CT. Rev. 39-66 (2005); Thomas E. Roberts, Ripeness and Forum Selection in Fifth Amendment Takings Litigation, 11 J. LAND UsE \& ENVTL. L. 37, 71 (1995) ("One understandable reaction to the prong two [state compensation procedures] requirement . . . is that it perpetrates a fraud or hoax on landowners. The courts say: 'Your suit is not ripe until you seek compensation from the state courts,', but when the landowner does these things, the court says: "Ha ha, now it is too late."); Berger, supra note 3, at 102 (describing the state procedures rule as applied by lower courts as "bizarre" and not "what the Williamson County court intended because it is inherently nonsensical and self-stultifying."); Overstreet, supra note 3, at 27 (state procedures requirement 
out providing any plausible justification for the outcome: the relegation of federal takings claims to state courts. ${ }^{65}$ Certainly, shutting takings plaintiffs out of the federal court system is wholly inconsistent with the Court's Section 1983 precedent, which recognizes that the "very purpose of $\S 1983$ was to interpose the federal courts between the States and the people, as guardians of the people's federal rights - to protect the people from unconstitutional action under color of state law, 'whether that action be executive, legislative, or judicial.' ",66

Williamson County's evisceration of the federal courts' ability

has "dramatic" and "absurd" application); Buchsbaum, supra note 3 at 473-74; ("This underlying premise [that the government has not] acted illegally until you ask for compensation and then it is denied is, of course, untrue."); Keller, supra note 3, at 240 ("The Supreme Court has stated that the Takings Clause of the Fifth Amendment should not be 'relegated' to a status below that of other provisions of the Bill of Rights. Yet, the Williamson County State Litigation prong does just that.”).

65 See The Story of the San Remo Hotel, supra note 3, at 283-90. In San Remo, the Court suggested that principles of state-federal comity might justify sending all takings claims to state courts. In so doing, the Court cited to its decision in Fair Assessment in Real Estate Association v. McNary, 454 U.S. 100 (1981), a case holding that claims challenging state taxation schemes should be decided by the state courts out of respect for their unique sovereignty in that particular area.

As Chief Justice Rehnquist observed in his concurring San Remo opinion, the Fair Assessment comity justification is insufficient to explain the banishing of Fifth Amendment takings claims from federal court. 545 U.S. at 349-50 (Rehnquist, C.J., concurring). First, if courtesy for state sovereignty justifies granting state courts exclusive jurisdiction over takings claims arising from local land use actions, the same principle should bar any federal constitutional claim arising from local controls. Id. But this is, of course, not the case. In fact, in the post-civil war framework, the need for federal review of alleged local and state civil rights violations has always trumped concern about interfering with state processes. Alabama Pub. Serv. Comm'n v. S. Ry. Co., 341 U.S. 341, 361 (1951) (Frankfurter, J., concurring) ("[I]t was never a doctrine of equity that a federal court should exercise its judicial discretion to dismiss a suit simply because a State court could entertain it.").

Aside from such general objections, the Fair Assessment comity case simply does not harbor any principle supporting the relegation of federal takings claims as a whole to state courts. Fair Assessment merely restricted federal review over one specific type of subject matter, state taxation codes. McNary, 454 U.S. at 116 (barring assertion of Section 1983 claims "against the validity of state taxation systems"). But the Williamson County/preclusion barrier sanctioned by San Remo goes much further. It is not a subject matter limitation; it redacts an entire constitutional provision - the Fifth Amendment- from the federal purview. San Remo, 545 U.S. at 346. It bars takings claims not just against state taxation, but against local and state land use regulation, physical invasions and so on. Id. at 347. No comity case supports this.

66 Patsy v. Bd. of Regents of Fla., 457 U.S. 496, 503 (1982) (quoting Mitchum v. Foster, 407 U.S. 225, 242 (1972)); see Felix Frankfurter \& James M. Landis, The Business of the Supreme Court of the United States: A Study in the Federal Judicial System, 40 Harv. L. REV. 834, 865 (1927); Stefel v. Thompson, 415 U.S. 452, 464 (1974) (stating that after the passage of 28 U.S.C. $\S 1331$, federal courts "became the primary and powerful reliances for vindicating every right given by the Constitution, laws, and treaties of the United States"). 
to review federal takings claims is deeply troubling on its own. But the resulting relegation of federal takings claimants to the state courts set the stage for yet another nasty snare for those claimants, this one arising from the interplay between the state litigation rule and a defendant's right to remove constitutionally-based state court cases to federal court. ${ }^{67}$

\section{Through Interaction with Federal Removal Jurisdiction, the State Litigation Rule Often Deprives Takings Claimants of Any Forum for their Claims}

The federal removal statute, 28 U.S.C. Section 1441(a), gives defendants power to transfer state court complaints that raise federal questions to the federal courts within thirty days after the complaint is filed in state court. ${ }^{68}$ As a claim arising under the federal Constitution, a federal takings claim appears to raise a basic federal question subject to review by a federal court. ${ }^{69}$ On the other hand, San Remo and Williamson County hold that a takings claim is not an issue for a federal court unless the claimant has fully completed a prior state court suit for just compensation. ${ }^{70}$

67 See Sansotta v. Town of Nags Head, 724 F.3d 533, 547 (4th Cir. 2013) (“[B]y removing to federal court [takings] claims properly filed in state court in accordance with San Remo Hotel and then claiming that the plaintiff cannot proceed on those claims, [the government is] thereby denying a plaintiff any forum for having his claim heard"); see supra notes $32,33,53$ and accompanying text.

6828 U.S.C. $\S 1441$ (a) (2006). The removal statute specifically provides that "any civil action brought in a State court of which the district courts of the United States have original jurisdiction, may be removed by the defendant or the defendants, to the district court of the United States for the district and division embracing the place where such action is pending." Metcalf v. City of Watertown, 128 U.S. 586, 589 (1888). Under 28 U.S.C. $§ 1331$, "District courts have original jurisdiction of all civil actions arising under the Constitution, laws, or treaties of the United States." Caterpillar Inc. v. Williams, 482 U.S. 386, 392 n.6 (1987). In determining whether a federal question exists, courts simply consider whether such a question is "presented on the face of the plaintiff's properly pleaded complaint." Id. Federal constitutional claims raise quintessential federal issues. Id.

69 Hammond v. City of Ladue, No. 4:10CV1977, 2010 WL 5392831, at *3 (E.D. Mo. Dec. 21, 2010) ("The alleged deprivation of Plaintiffs' property rights stated a substantial federal question claim under the Constitution. In particular, Plaintiffs' inverse condemnation claim . . . rests upon the Fifth Amendment . . .."); Morris v. Schirard, No. 10-cv-01145PAB-BNB, 2010 WL 3002052, at *1 (D. Col. July 28, 2010) ("Because plaintiff is asserting a [due process/takings] claim under the United States Constitution, this Court has jurisdiction over this action, and defendants had a right to remove the case to this Court.").

70 Williamson Cnty., 473 U.S. at 194-95; San Remo, 545 U.S. at 347; Adam Bros. Farming, Inc. v. Cnty. of Santa Barbara, 604 F.3d 1142, 1147-48 ("When the state provides a 
Due to this clash between the state litigation doctrine and the federal question character of a federal takings claim, the exercise of removal in the takings context can, and often does, deprive takings plaintiffs of any forum for their claims. Through removal, the government defendant can take a federal takings claim out of the state court forum on federal question grounds and bring it into the federal court before the plaintiff completed state court litigation. This opens the way for the defendant to argue that the removed takings claim is unripe in federal court under Williamson County. ${ }^{71}$ Despite the obvious ironies in this argument, courts often accept the argument, and dismiss the removed takings claim. ${ }^{72}$ Alternatively, federal courts simply conclude, on their own, that a removed takings claim is unripe in the federal forum under a literal application of Williamson County's state litigation requirement. ${ }^{73}$

The case of 8679 Trout, LLC v. North Tahoe Public Utilities District ${ }^{74}$ provides an apt example. There, a property owner sued a utility district in state court, alleging a takings violation and various state law violations, after it was denied variances to convert a small,

procedure by which a party may seek just compensation, such as an inverse condemnation cause of action, the plaintiff must seek relief in state court before bringing a claim in federal court.").

71 See, e.g., Del-Prairie Stock Farm, Inc. v. Cnty. of Walworth, 572 F. Supp. 2d 1031, 1032 (E.D. Wis. 2008) ("Defendants removed the case based on plaintiff's federal takings and substantive due process claims. However, defendants now move for summary judgment, arguing, among other things, that I have no jurisdiction over plaintiff's federal law claims because under [Williamson County] they are not ripe."); Oakland 40 LLC v. City of South Lyon, No. 10-14456, 2011 U.S. Dist. Lexis 53158, at *2, *4 (E.D. Mich. May 18, 2011) (illustrating situation where defendant removes a federal takings claim and then, when plaintiff files a motion to remand, files a motion to dismiss on the basis that plaintiff did not exhaust state court proceedings); Doney v. Pacific Cnty., NO. C07-5123RJB, 2007 U.S. Dist. LEXIS 34071, at $* 14$ (W.D. Wash. May 9, 2007) (arguing that removal of a federal takings claim was proper because it implicates a federal question, defendant thereafter asserted the federal court must dismiss the takings claim due to plaintiff's inability to exhaust state procedures).

72 See infra note 97.

73 See, e.g., Kunzelman v. City of Scottsdale, No. CV-10-0056-PHX-GMS, 2011 WL 3510883 (D. Ariz. Aug. 10, 2011). There, the Court held:

To their credit, Plaintiffs did initially file this action in state court. However the state court proceedings must run their course, as there must be a denial of compensation following those proceedings for Plaintiffs to claim they suffered a federal constitutional injury through a regulatory taking of their property. On its own motion, the Court must dismiss the as-applied takings claim without prejudice.

Id. at $* 11$.

74 No. 2:10-cv-01569, 2010 U.S. Dist. LEXIS 93303 (E.D. Cal. Sept. 8, 2010). 
seven-unit mobile home park from rental use to resident ownership. ${ }^{75}$ The District removed the case to federal court and moved to dismiss under Williamson County. ${ }^{76}$

The federal court recognized that the defendant had used removal to change the state of the property owner's claim from ripe (in state court) to unripe (in federal court). It nevertheless granted the motion to dismiss:

Because Defendants removed this litigation from state court, Plaintiff was denied the opportunity to seek state reimbursement. As ripeness is a threshold jurisdictional question, Defendants cannot confer jurisdiction to this Court by removal. Therefore, Plaintiff has yet to satisfy the requirements under the Williamson analysis to make its claim ripe for federal court adjudication. Although the claim was ripe when it was originally filed in state court, it became unripe the moment that Defendants removed it. A state action is "not complete until the state fails to provide adequate compensation for the taking." $" 77$

The court concluded: "Plaintiff"s Fifth Amendment takings claim is dismissed without prejudice for lack of jurisdiction."

The federal reporter is filled with many other federal deci-

\footnotetext{
$75 \quad$ Id. at $* 1-4$.

$76 I d$. at $* 4$. For its part, the plaintiff sought to stay its federal takings claims so it could pursue compensation in state court. $I d$.

77 Id. at *13-14 (citing Williamson Cnty., 473 U.S. at 195).

788679 Trout, LLC, 2010 U.S. Dist. LEXIS 93303 at*14. It should be noted here that removed takings claims dismissed from federal court for lack of state procedures ripeness are typically dismissed without prejudice and, therefore, may be re-filed in state court. See, e.g., id. at $* 13$. Re-filing is, however, an unrealistic option in most takings removal cases. First, the statute of limitations for filing a takings claim in state court may potentially run during the removal and federal litigation period, precluding a second state suit. See, e.g., Shands v. City of Marathon, 999 So. 2d 718, 726 (Fla. App. 2008) (holding statute of limitations runs from the final agency decision); Behavioral Inst. of Ind. v. Hobart Common Council, 406 F.3d 926, 929 (7th Cir. 2004) (holding the statute of limitations for Section 1983 claims is the two year period applicable to personal injury claims). Second, if a takings claim is re-filed in state court, there is nothing to prevent the takings defendant from removing the suit again, and thus from forcing the plaintiff to go through the same fruitless removal/ripeness/remand cycle. Mirto v. Am. Int'l Group, Inc., No. C-04-4998-VRWG, 2005 WL 827093 , at *3 (N.D. Cal. April 8, 2005) (noting in a different context that a wrongly removed claim could be subjected again to removal if dismissed without prejudice and then refiled in state court). Finally, it is often more financially feasible to simply abandon a dismissed takings claim and continue litigation of other claims not subject to Williamson County.
} 
sions dismissing a federal takings claim as unripe under Williamson County after removal short-circuited state court litigation and brought the claim to federal court in a premature state. ${ }^{79}$ In some removed takings cases, the state litigation ripeness problem remains hidden in federal court until substantial federal litigation has occurred on the merits of the takings claim. ${ }^{80}$ But once a federal court hearing a removed takings claim becomes aware of the state litigation requirement, the claim is often immediately dismissed even though the parties and the court may have already expended substantial resources litigating it in the federal forum. ${ }^{81}$

Federal cases dismissing a removed takings claim based on non-compliance with the state litigation rule are jarring because the takings plaintiff followed Williamson County perfectly. By filing in state court, that plaintiff did exactly what is required to prosecute a federal takings claim on the merits. And yet, through no fault of her own, the plaintiff's ripe state court claim instantly becomes noncompliant with Williamson County when the defendant removes the claim. She cannot remain in state court due to removal and she cannot remain in federal court after removal due to Williamson County. As one court put it: "Defendants' decision to remove this case from state court effectively denied [the plaintiff] an opportunity to utilize [the state's] procedure for reimbursement, and brought a takings claim to this [federal] Court that was not ripe for review." 82 In this way, the state litigation rule gives takings defendants unilateral power to defeat a federal takings claim without any review on the merits

79 Koscielski v. City of Minneapolis, 435 F.3d 898, 903 (8th Cir. 2006); Rau v. City of Garden Plain, 76 F. Supp. 2d 1173, 1174-75 (D. Kan. 1999); Ohad Assoc. LLC v. Twp. of Marlboro, No. 10-2183, 2011 U.S. Dist. LEXIS 8414, at *4, *6 (D. N.J. Jan. 28, 2011); Hendrix v. Plambeck, 1:09-cv-99-SEB-DML, 2010 U.S. Dist. LEXIS 92140, at*17-19 (S.D. Ind. Sept. 2, 2010); AM Rodriguez Assocs. v. City Council, No. 1:08-CV-214, 2009 U.S. Dist. LEXIS 110998, at *9 (W.D. Mich. Nov. 30, 2009); Thomas v. Shelby Cnty., No. 062433 Ml/P, 2006 U.S. Dist. LEXIS 94365, at *10-11 (W.D. Tenn. Dec. 12, 2006); Jones v. City of McMinnville, No. 04-0047-AA, 2004 U.S. Dist. LEXIS 7250, at *6 (D. Or. April 20, 2004); Bass v. City of Dallas, NO. 3-97-CV-2327-BD, 1998 U.S. Dist. LEXIS 11263, at*11 (N.D. Tex. July 21, 1998); Standard Materials Inc. v. City of Slidell, NO. 92-2509, 1994 U.S. Dist. LEXIS 8470, at *11 (E.D. La. June 21, 1994).

80 Reahard v. Lee Cnty., 30 F.3d 1412, 1418 (11th Cir. 1994) (holding a removed takings claim to be unripe for lack of state litigation ripeness on appeal, after the claim was fully litigated on the merits in district court); Sandy Creek Investors, Ltd. v. City of Jonestown, 325 F.3d 623 (5th Cir. 2003); Anderson v. Town of Groveling, 134 F. Supp. 2d 156, 157 (D. Mass. 2001).

$81 \quad$ See Kunzelman, 2011 U.S. Dist. LEXIS 89179.

82 Doak Homes, Inc. v. City of Tukwila, No. C07-1148MJP, 2008 U.S. Dist. LEXIS 7740, at $* 11$ (W.D. Wash. Jan 18, 2008). 
simply by choosing to remove it. A plaintiff's compliance with Williamson County's demand for state court litigation sets him up to be dragged by a removing defendant from state court into a federal jurisdictional dead zone, where no takings adjudication can occur.

In some removed takings cases, courts have remanded, rather than dismissed, a removed takings claim to state court upon concluding that the claim is not compliant with Williamson County's state litigation requirement. ${ }^{83}$ This remand solution is legally questionable. ${ }^{84}$ As a practical matter, it is hardly more preferable than outright dismissal of the claim. The removed and remanded takings plaintiff has been involuntarily yanked from the state court-which is the only proper forum for a takings claim - to a federal court - which is not a proper forum - only to be sent back to the state court because the claim cannot be heard in federal court until the plaintiff litigates his claims in state court-where it all began.

In the meantime, the takings plaintiff's resources and morale have been drained, ${ }^{85}$ and his takings claim is no closer to adjudication

83 Oakland, 40 LLC, 2011 U.S. Dist. LEXIS 53158, at *8; Clark v. Town of E. Hampton, 757 F. Supp. 2d 121, 123 (E.D.N.Y. 2010); Lohman Props., LLC v. City of Las Cruces, No. CV 08-875, 2009 U.S. Dist. LEXIS 47146, at *6-7 (D.N.M. April 20, 2009); Milliken v. Town of Addison, No. 3:02-CV-1164-D, 2002 U.S. Dist. LEXIS 17237, at *14 (N.D. Tex. Sept. 13, 2002); Doney, 2007 U.S. Dist. LEXIS 34071, at *21-22; Woodlake Partners Inc. v. Guadalupe Cnty., No. 511-CV-00647-XR, 2011 U.S. Dist. LEXIS 133161, at *5,*7 (W.D. Tex. Nov. 17, 2011).

Unlike cases dismissing removed takings claims as unripe, decisions that remand such claims arise from a court's conclusion that removal was improper from the start because the state litigation requirement is jurisdictional and a plaintiff's noncompliance with the requirement precludes original federal jurisdiction. See, e.g., Evans v. Washington Cnty., No. 991356, 1999 U.S. Dist. LEXIS 20036, at*20 (D. Or. Dec. 10, 1999) ("Because this court does not have federal question jurisdiction over this action under 28 USC $\S 1331$, removal to this court was improper under 28 USC § 1441.”); Carrollton Props., Ltd. v. City of Carrollton, No. 406-CV-308, 2006 U.S. Dist. LEXIS 65432, at *4 (E.D. Tex. Sept. 1, 2006) (ordering remand after observing that "[p]laintiffs have not unsuccessfully pursued just compensation in state court, thus the claim is not ripe, and it is not a [removable] federal question"). The "no original jurisdiction" conclusion triggers a section of the removal statute providing that "[i]f at any time before final judgment it appears that the district court lacks subject matter jurisdiction [over a removed complaint], the case shall be remanded." 28 U.S.C. $\S$ 1447(c) (2006) (emphasis added).

84 Remanding a removed takings claim to state court because the claim is unripe under the state litigation rule is questionable because remand can only occur under the removal statute if the court lacks original jurisdiction over a removed claim. Id. Yet, it is now clear that the state litigation rule is not a predicate to federal jurisdiction. See Stop the Beach, 560 U.S. at 728. This suggests that the removal statute may not authorize remand of a federal takings claim simply because it not compliant with the state litigation rule. Id.

85 See Martin v. Franklin Capital Corp., 546 U.S. 132, 140 (2005) ("The process of removing a case to federal court and then having it remanded back to state court delays reso- 
than on the day it was filed. His claims very likely have now been split, so that he now has two suits to prosecute, the takings claims in state court and any federal, non-takings claims in federal court.

The Supreme Court has said that takings claimants do not have to endure "piecemeal litigation or otherwise unfair procedures." ${ }^{86}$ Yet, this is exactly what they go through when a court remands a takings claim because removal rendered it unripe under the state litigation requirement. The government defendant may not obtain a total triumph over the takings claim in this removal/remand scenario, but it often secures the same practical result when the plaintiff abandons the remanded federal takings claim due to financial exhaustion or infeasibility of piecemeal prosecution.

No other constitutional claim is subject to such dysfunction in the removal process. ${ }^{87}$ To be sure, as a general matter, a defendant can argue in federal court that a removed claim is unripe. But it is only in takings cases, and only because of Williamson County, that a defendant can argue that a removed claim is unripe due to lack of prior state court litigation; i.e., because removal itself thwarted the state court predicate for ripeness. ${ }^{88}$

Takings litigation is a Kafkaesque journey to nowhere in most cases due to the state litigation requirement's interaction with preexisting jurisdictional doctrines such as preclusion and removal. The most basic decision in constitutional litigation-where and when to file a complaint - usually leads to a prolonged forum-chasing nightmare in the takings context, no matter the choice that is made. If the Fifth Amendment's prohibition on uncompensated takings is to sur-

lution of the case, imposes additional costs on both parties, and wastes judicial resources."); Mich. DOT v. Detroit Int'l Bridge Co., No. 10-13767, 2010 U.S. Dist. LEXIS 125236, at *5 (E.D. Mich. Nov. 29, 2010) (awarding more than $\$ 30,000$ to plaintiff after improper removal of a case because this was the amount the plaintiff had to expend to secure remand).

86 See MacDonald, Sommer, \& Frates v. Yolo Cnty., 477 U.S. 340, 350 n.7 (1986).

87 See Gideon Kanner, "[Un]equal Justice Under Law”: The Invidiously Disparate Treatment of American Property Owners in Taking Cases, 40 LoY. L.A. L. REV. 1065, $1077-$ 78 (2007) (decrying a "legal regime in which, as required by Williamson County, aggrieved property owners who are denied access to the federal forum duly file their takings cases in state courts only to have the government defendants remove them to federal courts, and once there, argue that the federal courts lack jurisdiction (on account of lack of ripeness) and that the cases must therefore be dismissed because the plaintiffs should have sued in state court first (which of course they did, or at least tried to do until the defendants removed the case unilaterally to federal court) ... [ [n]o other species of American plaintiffs are subjected to such judicial jiggery-pokery.").

${ }_{88}$ DLX, Inc., 381 F.3d at 521 ("[O]ther $§ 1983$ plaintiffs do not have the requirement of filing prior state-court actions."). 
vive as a judicially enforceable individual right, ${ }^{89}$ courts must remedy the takings removal problem and the federal preclusion barrier. Since San Remo refused to loosen preclusion rules in takings cases to account for the state litigation rule and there is no sign that courts will alter the federal removal doctrine in the takings context, the only hope for change lies in a modification, or abandonment, of the state litigation ripeness doctrine. At the least, the doctrine must become less rigid and less tolerant of the inequities it causes if property owners are to obtain reasonable access to the courts for their federal takings claims. Fortunately, that change appears to be occurring.

\section{With THE Supreme CourT's Blessing, Federal Courts ARE Transforming THE STATE Litigation RULE FROM A JURISDICTIONAL BARRIER INTO A DISCRETIONARY, FLEXIBLE CONCEPT THAT CAN BE WAIVED}

For most of Williamson County's existence, lower courts have viewed the state litigation ripeness requirement as a jurisdictional predicate. ${ }^{90}$ This understanding has been instrumental in the development of the claim/issue preclusion trap and removal problem experienced by takings plaintiffs complying with Williamson County. When the state litigation rule is jurisdictional, would-be federal takings claimants cannot sue directly in federal court, but must file some sort of action seeking damages in state court. ${ }^{91}$ This ensures that preclusion barriers will apply to any subsequent federal court suit, ${ }^{92}$ that

\footnotetext{
89 Because of the difficulty and expense of securing judicial review of a federal takings claim under Williamson County, property owners subject to actions traditionally challenged under a takings theory are increasingly foregoing their Fifth Amendment rights in favor of claims arising under due process and equal protection concepts. See, e.g., Penner v. City of Topeka, 437 Fed. Appx. 751, 753 (10th Cir. 2011) (involving due process and equal protection claims, but no takings claims, challenging repeated denials of land use permits); Ziss Bros. Const. Co. v. City of Independence, 439 Fed. Appx. 467, 470 (6th Cir. 2011) (involving a denial of development plat challenged only on due process and equal protection grounds).

90 See, e.g., Samaad v. City of Dallas, 940 F.2d 925, 934 (5th Cir. 1991); Reahard, 30 F.3d at 1418. The jurisdictional understanding dominated the courts' consideration of the state litigation rule even after the Supreme Court, somewhat casually, described Williamson County as a whole as a "prudential" doctrine in Suitum v. Tahoe Regional Planning Agency, 520 U.S. 725, 733-34 (1997) (involving the final decision ripeness rule).

91 Reahard, 30 F.3d at 1418 ("[U]ntil [plaintiffs] have pursued their state remedy, the federal courts are without subject matter jurisdiction.").

92 See, e.g., DLX, Inc., 381 F.3d at 520-21; Wilkinson v. Pitkin Cnty. Bd. of Cnty. Comm'rs, 142 F.3d 1319, 1324 (10th Cir. 1998); W.J.F. Realty Corp., 220 F. Supp. 2d at
} 146. 
the plaintiff must, therefore, raise his federal takings claim in a state court action, and that a defendant can potentially use removal to pull the case into federal court in an unripe state, setting the stage for the plaintiff to lose his federal claim completely. ${ }^{93}$

Fortunately, federal courts are abandoning the jurisdictional understanding of Williamson County. Many have explicitly recast the state litigation rule as a non-jurisdictional, prudential ripeness concept. $^{94}$ This characterization changes the essential issue in a state litigation ripeness case from whether the property owner has complied with the requirement, by fully exhausting state court litigation, to whether a federal court "should" require prior state court litigation. ${ }^{95}$ The discretionary nature of the issue allows federal courts to choose to immediately hear a takings claim, thereby avoiding state court litigation and negating the preclusion and removal traps that go along with it.

\section{A. The Supreme Court's Decisions}

The Supreme Court has led the way in the repositioning of Williamson County as a discretionary, prudential ripeness doctrine. In San Remo, the concurring justices noted that the state litigation rule had to be "merely a prudential rule, and not a constitutional mandate" if plaintiffs could raise a Fifth Amendment takings claim in state court without first litigating a state law takings claim, as the San Remo majority had held. ${ }^{96}$

93 See, e.g., Koscielski, 435 F.3d at 903 (rejecting argument that the state litigation ripeness rule could be waived after removal of a takings case because this "would require the Court to refuse to consider whether it has subject matter jurisdiction over the case," and dismissing a federal takings claim under the state litigation doctrine after removal for lack of jurisdiction) (emphasis added); see Sansotta, 724 F.3d at 547 (questioning if the government can remove a takings and invoke Williamson County as bar to federal review because it is "denying a plaintiff any forum for having his claim heard").

94 See infra notes 97-99.

95 Washlefske v. Winston, 234 F.3d 179, 182 (4th Cir. 2000) (stating that a prudential ripeness analysis considers whether the court "should exercise federal jurisdiction"); Thomas v. Anchorage Equal Rights Comm'n, 220 F.3d 1134, 1142 (9th Cir. 1999) (en banc) ("Prudential considerations of ripeness are discretionary . . . ."); see also McClung v. City of Sumner, 548 F.3d 1219, 1224 (9th Cir. 2008) ("Because this case raises only prudential ripeness concerns, we have discretion to assume ripeness is met ....").

96 San Remo, 545 U.S. at 351 n.2 (Rehnquist, C.J., concurring) (noting that the Court holds that "Williamson County does not command that the state courts themselves impose the state-litigation requirement. But that is so only if Williamson County's state-litigation requirement is merely a prudential rule, and not a constitutional mandate ...."). 
Then, in the 2010 case of Stop the Beach, the Court rejected the argument that a takings claim was "unripe because petitioner has not [previously] sought just compensation" on the ground that the argument was not raised below and was not "jurisdictional." 97 The Court made essentially the same observation in its recent decision in Horne v. U.S. Department of Agriculture, ${ }^{98}$ when it stated that "a Fifth Amendment claim is premature until it is clear that the Government has both taken property and denied just compensation. Although we often refer to this consideration as 'prudential ripeness,' we have recognized that it is not, strictly speaking, jurisdictional." 99 These decisions clearly show that state litigation can no longer be treated as a necessary predicate to a federal court's power to hear a federal takings claim.

\section{B. Lower Court Decisions}

Many circuit courts that have faced Williamson County issues since the Court's decisions in San Remo and Stop the Beach have concluded that the state litigation rule is a prudential ripeness concept and can no longer be applied as a jurisdictional bar. Others have yet to take a definitive position. A few circuits continue to wrongly cling to a jurisdictional understanding of Williamson County's state litigation rule - though this is most likely because these particular courts have not recently faced the issue.

\section{Prudential Circuits}

The Fourth, ${ }^{100}$ Fifth, ${ }^{101}$ and Ninth ${ }^{102}$ Circuit Courts now une-

$97 \quad$ Stop the Beach, 560 U.S. at 729.

$98 \quad 133$ S. Ct. 2053 (2013).

99 Id. at 2062 (citations omitted).

100 Town of Nags Head v. Toloczko, 728 F.3d 391, 399 (4th Cir. 2013); Sansotta, 724 F.3d at 545 ("Williamson County is a prudential rather than a jurisdictional rule"); Acorn Land, LLC v. Baltimore Cnty., 402 Fed. Appx. 809, 813 (4th Cir. 2010) ("[T]he Supreme Court has clarified that Williamson's ripeness prongs are 'prudential hurdles,' [and] not jurisdictional requirements.”) (citations omitted); Washlefske, 234 F.3d at 182 (4th Cir. 2000).

101 Rosedale Missionary Baptist Church v. New Orleans City, 641 F.3d 86, 88-89 (5th Cir. 2011) (citing San Remo and Stop the Beach, the court "held that Williamson County's ripeness requirements are merely prudential" and a prior decision considering it to raise jurisdictional barriers was "no longer good law").

102 Guggenheim v. City of Goleta, 638 F.3d 1111, 1118 (9th Cir. 2010) (en banc) (stating the ripeness requirement now appears to be prudential rather than jurisdictional); Adam Bros. Farming, 604 F.3d at 1148 (9th Cir. 2010); McClung, 548 F.3d at 1224. 
quivocally consider the state litigation requirement to be nonjurisdictional. Both the Ninth and Fifth Circuits previously treated Williamson County's state litigation rule as a rigid jurisdictional barrier, but since San Remo and Stop the Beach, they have adopted a prudential view of the rule. ${ }^{103}$

\section{On the Fence: Third, Sixth, Seventh, and Tenth Circuits}

The Third, Tenth, and Seventh Circuit Courts appear to recognize that Williamson County is rooted in prudential ripeness concepts, but have yet to conclude that this means the state litigation requirement is not a jurisdictional bar. ${ }^{104}$ Courts in these circuits must, and most likely will, make this leap soon. The "prudential" designation given to Williamson County ripeness by the Supreme Court is not an empty rhetorical device. The very purpose of the designation is to distinguish the state litigation rule as a non-jurisdictional ripeness concept. ${ }^{105}$

\section{Jurisdictional Holdouts}

The operative precedent of the First, Second, and Eighth Circuit Courts reflects the outdated and erroneous notion that the state litigation requirement is jurisdictional. ${ }^{106}$ Notably, most of this prec-

103 See Rosedale Missionary Baptist Church, 641 F.3d at 88-89, 89 n.2; Guggenheim, 638 F.3d at 1117-18 (tracing evolution of Ninth Circuit's understanding that the state litigation requirement is a prudential rather than jurisdictional rule).

104 See Cnty. Concrete Corp. v. Twp. of Roxbury, 442 F.3d 159, 164 (3d Cir. 2006); Alto Eldorado P'ship v. Cnty. of Santa Fe, 634 F.3d 1170, 1173, 1179 (10th Cir. 2011); Peters v. Village of Clifton, 498 F.3d 727, 734 (7th Cir. 2007) (“Williamson County's ripeness requirements are prudential in nature. The prudential character of the Williamson County requirements do not, however, give the lower federal courts license to disregard them."). Compare Miles Christi Religious Order v. Twp. of Northville, 629 F.3d 533, 541 (6th Cir. 2010), and id. at 545 (Batchelder, C.J., dissenting) (discussing and agreeing on prudential nature of Williamson County), with Braun v. Ann Arbor Charter Two, 519 F.3d 564, 571 (6th Cir. 2008) ("Because the plaintiffs did not fulfill their obligation of seeking just compensation in state court, we do not have jurisdiction ....”).

105 See Stop the Beach, 560 U.S. at 729; Horne, 133 S. Ct. at 2062 (noting that the phrase "prudential 'ripeness" does not mean Williamson County is "jurisdictional").

106 See, e.g., Downing/Salt Pond Partners, L.P. v. Rhode Island \& Providence Plantations, 643 F.3d 16, 20 (1st Cir. 2011) ("In Williamson County, the Supreme Court held that the nature of a federal regulatory takings claim gives rise to two ripeness requirements which plaintiffs bear the burden of proving they have met before a federal court has jurisdiction over a takings claim."); Snaza, 548 F.3d at 1182 (8th Cir. 2008) ("Snaza contends that . . 
edent pre-dates recent Supreme Court decisions, like Stop the Beach, holding that the state litigation rule is a prudential rule. They are therefore of dubious precedential value. In any event, there is absolutely no basis in the Court's jurisprudence for continuance of this approach to Williamson County.

\section{Courts Adopting the Prudential View Are Declining to Apply the State Litigation Requirement Based on Fairness and Efficiency Concerns}

Federal courts which have found the state litigation rule to be a prudential ripeness rule, have concluded this status gives them discretion to decline to apply or enforce the rule in certain circumstances. ${ }^{107}$ In particular, a number of circuit courts have held that the state litigation requirement is waived, and the takings plaintiff exempted from its application, when a defendant does not affirmatively raise or preserve the Williamson County ripeness issue. ${ }^{108}$ The Supreme Court itself came to this conclusion in Stop the Beach. ${ }^{109}$ Going one step further, some circuit courts have held that federal courts can waive the state litigation requirement on their own, based on its prudential character, even when the defendant has properly preserved the issue. ${ }^{110}$

Still other federal courts have held they may refuse to apply the state litigation requirement on the ground that considerations relevant to prudential ripeness, such as efficiency, judicial economy,

Williamson County . . . is prudential rather than jurisdictional and so does not bar us from exercising discretion to decide the takings question now. She cites cases from the Ninth Circuit . . . but we have held that Williamson County is jurisdictional."); see also Island Park, LLC v. CSX Transp., 559 F.3d 96, 110 (2d Cir. 2009).

107 See, e.g., Guggenheim, 638 F.3d at 1118 ("[We] exercise our discretion not to impose the prudential requirement of exhaustion in state court."); Adam Bros. Farming, 604 F.3d at 1147-48 (holding the court had discretion to waive the Williamson exhaustion requirement when the case raised only prudential ripeness concerns).

108 See, e.g., Acorn Land, 402 Fed. Appx. at 813; Rosedale Missionary Baptist Church, 641 F.3d at 88-89 ("[A]lthough a court may raise [Williamson County's requirements] sua sponte, it may consider them waived or forfeited as well."); see also Guggenheim v. City of Goleta, 582 F.3d 996, 1009 (9th Cir. 2009), vacated on reh'g en banc, 638 F.3d 1111 (9th Cir. 2010) ("[T]he City of Goleta forfeited the claim that this case was not ripe for review by failing to raise it.").

109560 U.S. at 729.

110 See, e.g., Guggenheim, 638 F.3d at 1118 (declining "to impose the prudential requirement of exhaustion in state court"); Adam Bros. Farming, 604 F.3d at 1148 (declining to apply the state litigation rule). 
and fairness, warrant immediate takings review. ${ }^{111}$ The leading example from a federal appellate court is Town of Nags Head v. Toloczko. ${ }^{112}$ Toloczko involved a federal takings claim and other claims that had been removed from state court to federal court by the plaintiff based on diversity jurisdiction. The Fourth Circuit noted that the owner's removal action rendered the takings claim non-compliant with Williamson County's state litigation rule. ${ }^{13}$ However, for prudential reasons, the court refused to apply the rule and to thereby require the takings claims be litigated in the state court system while other claims were decided in federal court. The court explained:

Because Williamson County is a prudential rather than a jurisdictional rule, we may determine that in some instances, the rule should not apply and we still have the power to decide the case. Exercise of such discretion may be particularly appropriate to avoid 'piecemeal litigation or otherwise unfair procedures.'

This is a proper case to exercise our discretion to suspend the state-litigation requirement of Williamson County. In the interests of fairness and judicial economy, we will not impose further rounds of litigation on the Toloczkos. ${ }^{114}$

Finally, in Sansotta v. Town of Nags Head, ${ }^{115}$ the Fourth Circuit used prudential ripeness considerations to directly confront the takings removal issue. The case dealt with a federal takings claim which the Town had removed from state court to federal court. After a year of litigation, the Town argued the removed claim was unripe under Williamson County's state litigation requirement. ${ }^{116}$ Sansotta rejected this contention. In so doing, the Fourth Circuit began by establishing the prudential and discretionary nature of the state litigation rule:

111 See, e.g., Toloczko, 728 F.3d at 399; Yamagiwa v. City of Half Moon Bay, 523 F. Supp. 2d 1036, 1108-10 (N.D. Cal. 2007); see also Guggenheim, 638 F.3d at 1118 (declining to apply the state litigation rule because "it would be a waste of the parties' and the courts' resources to bounce the case through more rounds of litigation" and "it is hard to see any value in forcing a second trip [to state court] on them").

112728 F.3d 391

Id. at 399.

Id. (citations omitted).

724 F.3d 533.

Sansotta, 724 F.3d at 545. 
Because Williamson County is a prudential rather than a jurisdictional rule, we may determine that in some instances, the rule should not apply and we still have the power to decide the case. This case is such an instance. Allowing the Town to invoke the Williamson County state-litigation requirement after removing the case to federal court would fail to fulfill the rationale for this prudential rule and would create the possibility for judicially condoned manipulation of litigation. ${ }^{117}$

Relying on equitable considerations, the court then held removal of a takings claim categorically waives the state litigation requirement;

[Waiving the state litigation rule in a removal case] protects an innocent plaintiff who sought to comply with Williamson County and San Remo Hotel but whose efforts were thwarted by the state or political subdivision's decision to remove the case . . . . [I]t prevents a state or its political subdivision from manipulating litigation by removing to federal court claims properly filed in state court in accordance with San Remo Hotel and then claiming that the plaintiff cannot proceed on those claims, thereby denying a plaintiff any forum for having his claim heard . . . [and] it furthers our 'strong preference for deciding cases on the merits' by preventing any procedural gamesmanship. ${ }^{118}$

As Toloczko and Sansotta show, courts construing the state litigation ripeness rule as a prudential concept may refuse to apply the rule when doing so would cause unfairness and/or an inefficient expenditure of court and party resources. Takings removal cases are an obvious candidate for the exercise of this discretion. The Fourth Circuit's ruling in Sansotta that federal courts can and should decline to enforce the state litigation rule after removal of a takings claim offers a sensible, prudential solution to the Williamson County/removal problem. ${ }^{119}$ Defendants can still remove a takings case; fairness and

\footnotetext{
$117 I d$. (first emphasis added) (citation omitted).

118 Id. at 546-47 (citation omitted).

119 See also Petersen v. Riverton City, No. 2:08-CV-664 SA, 2009 WL 564392, at *2 (D. Utah March 5, 2009) ("During oral arguments, Defendant asserted that although San Remo Hotel states that Plaintiffs can bring state and federal takings actions in the same case,
} 
other prudential considerations simply prevent them from subsequently arguing that the removed claim is unripe because the plaintiff failed to fully litigate in state court.

The Williamson County/preclusion trap also loses its teeth, at least in some cases, when the state litigation rule is construed as a discretionary prudential ripeness concept. As previously noted, the preclusion barrier to federal takings review arises from a rigid, jurisdictional conception of the state litigation requirement, one that always requires takings plaintiffs to litigate in state court before resorting to federal court. ${ }^{120}$ When the state litigation requirement is prudential and discretionary, some federal takings complaints can be filed directly in federal court ${ }^{121}$ and this leaves no room for a preclusion barrier based on prior state litigation.

\section{Courts Are Correct to Consider Fairness and Efficiency in Deciding Whether to Apply the Prudential State Litigation Rule}

As courts fashion more exceptions to the state litigation rule on the ground that the rule is prudential and discretionary, the correctness of this approach is likely to be questioned.

But there is little reason for concern. Courts in the nontakings context have long held that prudential ripeness concepts are discretionary and flexible, ${ }^{122}$ and can be waived. ${ }^{123}$ Moreover, such courts have routinely weighed considerations such as fairness to the parties ${ }^{124}$-including whether the plaintiff might lose a claim if review is withheld, ${ }^{125}$ judicial economy and efficiency, ${ }^{126}$ and the histo-

that Plaintiffs' federal claims should still be dismissed and the state claims sent back to state court because the state courts are better suited to address state constitutional claims. Such a procedure is not required by San Remo Hotel and would be unduly burdensome to Plaintiffs. Plaintiffs filed this case in state court. Defendants then chose to remove it to this court. In doing so, Defendants chose to have the federal court decide Plaintiffs' state constitutional claim.").

120 See supra notes 2-3 and accompanying text.

121 Toloczko, 728 F.3d at 399.

122 Anchorage Equal Rights Comm'n, 220 F.3d at 1142 ("Prudential considerations of ripeness are discretionary.”); American Sav. Bank, FSB v. UBS Fin. Servs., Inc., 347 F.3d 436, 439 (2d Cir. 2003) (“' '[P]rudential ripeness' . . . [is] 'a more flexible doctrine of judicial prudence ....'”) (internal citations omitted).

123 Stolt-Nielsen S.A. v. AnimalFeeds Int'l Corp., 559 U.S. 662, 670 n.2 (2010).

124 Abbott Labs. v. Gardner, 387 U.S. 136, 149 (1967) (finding courts should consider "the hardship to the parties of withholding court consideration").

125 In re Methyl Tertiary Butyl Ether ("MTBE") Prod. Liab. Litig., 725 F.3d 65, 110 
ry of the litigation, in deciding whether to hold a claim prudentially ripe and afford immediate judicial review.

Courts are therefore well within the mainstream of prudential ripeness law when they apply, or decline to apply, Williamson County's state litigation ripeness rule based on prudential considerations. Indeed, courts are on more solid ground in giving great weight to fairness and efficiency concerns in the takings ripeness context, than in other areas, in light of the Supreme Court's oft-repeated admonition that takings ripeness doctrine does not require "unfair" procedures or "piecemeal litigation."."27

\section{CONCLUSION}

Williamson County's decision to hinge the accrual and ripeness of a federal takings claim on a state court's denial of damages is doctrinally bankrupt and unworkable in practice. ${ }^{128}$ By requiring state court litigation to ensure a taking is "without just compensation," and fit for federal review, the Williamson County Court set the stage for property owners to lose access to the courts for protection of their Fifth Amendment rights. A property owner who sues under state law in state court to ripen a federal takings claim will find that preclusion rules prevent the claim from being subsequently filed. But if he files a Fifth Amendment takings claim in the state court, as San Remo indicates is proper, the claim can be immediately removed to federal court, where that court will likely hold it unripe due to the inchoate state court procedures. ${ }^{129}$

In light of these defects, the state litigation ripeness rule should be overruled. ${ }^{130}$ Unfortunately, that has not occurred. Nevertheless, the state litigation ripeness requirement is not the monster it

(2d Cir. 2013).

126 United States v. Wayne, 591 F.3d 1326, 1329 n.1 (10th Cir 2010) (“[A] finding of ripeness promotes judicial efficiency ... [and] this court has an interest in expeditiously resolving this action, rather than remanding it ....").

127 San Remo, 545 U.S. at 346; MacDonald, Sommer \& Frates, 477 U.S. at 350 n.7; see also Palazzolo v. Rhode Island, 533 U.S. 606, 621 (2001) ("Government authorities, of course, may not burden property by imposition of repetitive or unfair land-use procedures in order to avoid a final decision.").

128 See supra note 48.

129 See supra notes 33, 70 and accompanying text.

130 See Lawrence v. Texas, 539 U.S. 558, 578 (2003) ("[A rule that] was not correct when it was decided, and . . . is not correct today . . . ought not to remain binding precedent."). 
once was. This is because the Supreme Court has recently and repeatedly clarified that the rule is not a jurisdictional predicate, but instead, a mere "prudential" ripeness concept. ${ }^{131}$

The rise of the prudential conception of the state litigation rule, and the related demise of the jurisdictional understanding, ${ }^{132}$ imbues federal courts with discretion in applying the requirement, including discretion to waive the state litigation rule. Government defendants - who could once count on courts to raise and apply the state litigation requirement sua sponte as a jurisdictional principlecan now be held to have waived the requirement if they do not affirmatively plead and argue it. ${ }^{133}$ More importantly, courts may also waive the state litigation ripeness requirement under their prudential ripeness discretion when a defendant chooses to thwart state litigation by removing a takings case. ${ }^{134}$ Without the jurisdictional view of Williamson County prompting federal courts to strictly apply the state litigation rule, government defendants no longer have a free pass to invoke the state litigation ripeness doctrine after removal of a state court takings case as to deny the plaintiff state court review (by removal) and a federal forum (by arguing the removed takings claim is unripe in federal court because the plaintiff did not exhaust state court litigation).

Post-San Remo circuit court decisions have identified other situations in which federal courts may adjudicate property rights claims notwithstanding a lack of compliance with Williamson County's state court litigation rule. Federal courts can, for instance, directly hear takings claims when considerations of fairness, judicial economy, and efficiency weigh against additional rounds of (state court) litigation. ${ }^{135}$ This approach negates the San Remo preclusion barri$\mathrm{er}^{136}$ that arises in federal court when a plaintiff has litigated in state court in a (futile) attempt to ripen federal review of a takings claim, and is entirely consistent with decisions applying prudential ripeness concepts in non-takings contexts and with background takings ripeness principles.

The conversion of the state litigation rule into a prudential 
concept and the lower courts' decision to view this as a license to decline to apply the rule probably arise from the persistent, general consensus that the requirement is not a well-reasoned or functional ripeness concept. The San Remo concurrence deserves particular credit for bringing Williamson County's flaws and its limited, "prudential" nature to the attention of the lower courts, and to the newer Supreme Court justices themselves. ${ }^{137}$ While that concurrence has not resulted in the total repudiation of the state litigation requirement, as former Chief Justice Rehnquist apparently hoped, it may very well have started the state litigation requirement on a slow death spiral. At the least, the Court's recent characterization of Williamson County as "prudential" gives lower courts a sound basis to spare takings plaintiffs from the worst injustices of the state litigation rule until the Supreme Court finally puts it where it belongs: in the waste pile of failed constitutional doctrines. ${ }^{138}$

137 See San Remo, 545 U.S. at 348-52 (Rehnquist, C.J., concurring).

138 Lingle v. Chevron U.S.A. Inc., 544 U.S. 528, 534 (2005) (repudiating the rule that a taking occurs when a regulation "fails to substantially advance legitimate state interest[s]" twenty-five years after that rule was articulated). 